\title{
Temas atuais da jurisprudência do Superior Tribunal de Justiça: algumas
}

\author{
polêmicas solucionadas pela Corte
}

\section{Current themes of the jurisprudence of the Superior Court of Justice:}

some controversies resolved by the Court

\author{
Marco Aurélio Ventura Peixoto ${ }^{1}$ \\ Rodrigo Frantz Becker ${ }^{2}$
}

\section{RESUMO}

O presente trabalho objetiva analisar alguns temas atuais, fruto da jurisprudência do Superior Tribunal de Justiça, a fim de demonstrar como a Corte responsável pela interpretação da lei federal tem se posicionado acerca das mais diversas questões relacionadas ao Código de Processo Civil de 2015, que completou recentemente quatro anos de vigência. Foram selecionados três assuntos para verificação, a necessidade de comprovação do feriado local para a interposição de recurso para o Superior Tribunal de Justiça, o cabimento da reclamação no controle da aplicação de tese de recursos repetitivos e, finalmente, a possibilidade de interposição de recurso especial contra decisões monocráticas.

Palavras-chave: Superior Tribunal de Justiça. Polêmicas. Código de Processo Civil.

\section{ABSTRACT}

The present work aims to analyze some current themes, the result of the jurisprudence of the Superior Court of Justice, in order to demonstrate how the Court responsible for the interpretation of the federal law has been positioned on the most diverse issues related to the Code of Civil Procedure of 2015, which completed recently four years in force. Three subjects were selected for verification, the need to prove the local holiday for filing an appeal with the Superior Court of Justice, the appropriateness of the complaint in controlling the application of the repetitive appeals thesis and, finally, the possibility of filing a special appeal. against monocratic decisions.

Keywords: Superior Justice Tribunal. Controversial. Code of Civil Procedure.

\footnotetext{
${ }^{1}$ Advogado da União. Mestre em Direito Público pela Universidade Federal de Pernambuco - UFPE. Especialista em Direito Público pela UnB. Membro do Instituto Brasileiro de Direito Processual - IBDP. Associado Fundador da ANNEP - Associação Norte e Nordeste de Professores de Processo, Professor Honorário da Escola Superior da Advocacia da OAB/PE, da Graduação em Direito do Centro Universitário Estácio do Recife, das Especializações em Direito Processual Civil da UFPE, do Centro Universitário Estácio do Recife, ATF Cursos, Esmatra VI,

IMADEC/MA, Facesf e Espaço Jurídico. Coordenador da Pós-Graduação em Advocacia Pública do IAJUF/Unirios. Diretor da Escola da AGU na $5^{\text {a }}$ Região. Conselheiro Seccional da OAB/PE.

${ }^{2}$ Advogado da União. Doutorando em direito processual pela UERJ. Mestre em Direito pela UnB. Ex-ProcuradorGeral da União. Consultor Jurídico do Governo do Distrito Federal. Professor da Graduação e da Pós-Graduação do IDP em Brasília e Goiânia e da Pós-Graduação da Atame. Membro-fundador e Presidente da ABPC (Associação Brasiliense de Direito Processual Civil). Membro do IBDP (Instituto Brasileiro de Direito Processual).
} 


\section{INTRODUÇÃO}

O Código de Processo Civil de 2015 completou cinco anos de existência e quatro anos de vigência em março de 2020. Muitas foram as discussões para que se chegasse ao texto final, bem como muitos foram os debates, notadamente no período de vacância da lei, quanto ao modo de interpretação do Poder Judiciário acerca de vários dos seus dispositivos.

Era esperado - e não poderia ser diferente - que à medida que as ações, incidentes ou recursos começassem a chegar ao Superior Tribunal de Justiça, guardião maior da legislação federal infraconstitucional, tal Corte passasse a proferir suas decisões, formadoras de precedentes qualificados ou não, que acabariam por nortear os Tribunais locais e juízos de primeiro grau.

Selecionamos, para análise no presente trabalho, três desses temas, objeto de repercussão entre os operadores do direito, quais sejam: a) a necessidade de comprovação do feriado local para a interposição de recurso para o STJ; b) o cabimento da reclamação no controle da aplicação de tese de recursos repetitivos; e c) a possibilidade de interposição de recurso especial contra decisões monocráticas.

\section{A (DES) NECESSIDADE DE COMPROVAÇÃO DE FERIADO LOCAL NA INTERPOSIÇÃO DO RECURSO PARA O STJ}

A Corte Especial do Superior Tribunal de Justiça, no âmbito do Recurso Especial 1.813.684/SP, concluiu pela necessidade de comprovação de feriado local na interposição do recurso, mas tão somente após a publicação do acórdão respectivo ${ }^{3}$.

A discussão não findou com tal acórdão, porque restou uma dúvida: se o entendimento poderia ser aplicado a todos os feriados, ou tão somente à segunda-feira de carnaval, objeto do recurso julgado. Assim, analisando-se Questão de Ordem naquele recurso especial, em sessão ocorrida no dia 03 de fevereiro de 2020, reconheceu-se que a tese firmada por ocasião do julgamento do recurso seria restrita ao feriado de segunda-feira de carnaval, não se aplicando aos demais feriados, inclusive aos feriados locais.

É sabido que a tempestividade é um dos requisitos extrínsecos dos recursos, que nada mais é senão a necessidade de interposição dentro do prazo estatuído em lei. Há uma regra geral prevista no $\S 5^{\circ}$ do art. 1.003 do CPC, que é de 15 (quinze) dias úteis, salvo no caso dos embargos

${ }^{3}$ REsp 1.813.684/SP, Rel. Ministro RAUL ARAÚJO, Rel.p/ Acórdão Ministro LUIS FELIPE SALOMÃO, CORTE ESPECIAL, julgado em 02/10/2019, DJe 18/11/2019. 
de declaração, que têm prazo de apenas 05 (cinco) dias úteis, devendo-se respeitar obviamente as prerrogativas de contagem de prazo em dobro previstas para o Ministério Público (art. 180), para a Advocacia Pública (art. 183), para a Defensoria Pública (art. 186) e para os litisconsortes com advogados de escritórios diferentes (art. 229), estes últimos apenas em se cuidando de processos que tramitam em autos físicos.

Diferentemente de outros requisitos, a verificação da tempestividade não guarda maiores dificuldades, visto que, sabendo-se o meio e a data de intimação da decisão objeto do recurso, bastará observar a data de protocolo, a fim de se apurar se foi ou não interposto tempestivamente. Os parágrafos do art. 1.003 do CPC detalham outros aspectos de tal requisito recursal, até mesmo para eliminar dúvidas que existiam como decorrência do art. 242 do CPC/73. Exemplo disso é o que está contido no $\S 4^{\circ}$, em que se prevê que, para a aferição da tempestividade do recurso remetido pelo correio, será considerada como data de interposição a data da postagem.

Por seu turno, no $\S 6^{\circ}$ do art. 1.003 há a previsão de que o recorrente comprovará a ocorrência de feriado local no ato de interposição do recurso. Dita exigência, segundo ensina Cássio Scarpinella Bueno (2016, p. 680), deve ser compreendida de forma ampla, para compreender não apenas o feriado que ocorre no último dia do prazo, mas qualquer feriado que se dê ao longo do prazo, já que somente nos dias úteis é que ele fluirá.

Tal inserção no CPC/2015 se deveu, por evidente, às inúmeras discussões - sob a égide do Código revogado - sobre ser ou não tempestivo o recurso interposto sem a demonstração do feriado local no ato da interposição.

$\mathrm{O}$ entendimento inicial, no âmbito do $\mathrm{STJ}$, durante a vigência do $\mathrm{CPC} / 73$, era restritivo, isto é, no sentido de que a comprovação do feriado local deveria se dar no ato de interposição do recurso na instância de origem, sendo vedada a comprovação posterior. Tal visão veio a ser flexibilizada no STJ, quando firmou-se a posição de que se presumia de conhecimento da Corte a suspensão do expediente forense previsto em norma de direito local, ficando a parte dispensada de juntar prova a respeito no momento da interposição do recurso, salvo se o Tribunal exigisse $^{4}$, ou seja, passou-se a permitir a prova posterior de eventual causa suspensiva ou interruptiva, aplicando-se o art. 337 daquele diploma.

Em 2006, a Corte Especial do STJ enfrentou o tema, no AgRg no Ag 708.460/SP, que teve como relator o Ministro Castro Filho, em que se consolidou o entendimento de que a comprovação deveria se dar no momento da interposição, com cópia da lei ou do ato gerador da

${ }^{4} \mathrm{AgRg}$ nos EDcl no AgRg no Ag 659.381/RJ, Rel. Ministro TEORI ALBINO ZAVASCKI, PRIMEIRA TURMA, julgado em 06/09/2005, DJ 19/09/2005. 
suspensão do prazo, ou ainda de certidão de quem de direito, servidor do tribunal de origem, de sorte que o silêncio da parte contrária, assim como a comprovação posterior, não serviriam para suprir a omissão do recorrente. ${ }^{5}$

Essa linha de raciocínio era também acolhida no Supremo Tribunal Federal. Ocorre que, nos autos do AgRg no RE 626.358/MG, nossa Corte Suprema passou a entender em sentido diverso, admitindo a comprovação posterior da tempestividade do recurso, quando a intempestividade decorresse de feriado local ou de suspensão do expediente forense, presumindo-se a boa-fé do recorrente ${ }^{6}$. Na doutrina, há vozes, como a de José Miguel Garcia Medina (2016, p. 1.471), no sentido da aplicabilidade dessa presunção de boa-fé inclusive em relação a outros recursos, de modo a admitir a comprovação posterior, sendo o caso até mesmo da aplicação do art. 932, parágrafo único, do CPC, com a concessão do prazo de cinco dias para o recorrente fazer a demonstração do feriado local. Para Flávio Cheim Jorge (2016, p. 2.447), conquanto o Código tenha adotado o entendimento mais restritivo à admissibilidade do recurso, nas situações em que o recorrente afirme, mas não comprove a existência do feriado, deve ser aplicado o disposto no art. 932, parágrafo único, oportunizando que, no prazo de cinco dias, traga aos autos a referida comprovação.

Isso gerou, como não poderia deixar de ser, uma mudança de posição do próprio STJ, a fim de acompanhar o que se decidira no âmbito do STF. Naquele mesmo ano, no AgRg no AREsp 137.141/SE, a Corte Especial decidiu que a comprovação da tempestividade do recurso especial, em decorrência de feriado local ou de suspensão de expediente forense no tribunal de origem, que implicasse prorrogação do termo final para interposição, poderia ocorrer posteriormente, em sede de agravo regimental. $^{7}$

Era esse o entendimento que predominava em nossas cortes superiores até que entrou em vigor o Código de Processo Civil de 2015, em março de 2016. Isto porque a previsão contida no referido $\S 6^{\circ}$ do art. 1.003 invariavelmente produziria uma reflexão no STF e no STJ quanto à desnecessidade de comprovação do feriado local no momento da interposição do recurso. Ainda em 2016, já era possível detectar no STF um retorno ao posicionamento anterior, qual fosse, na linha da exigência de comprovação quando da interposição, conforme se verifica do ARE

${ }^{5} \mathrm{AgRg}$ no Ag 708.460/SP, Rel. Ministro CASTRO FILHO, CORTE ESPECIAL, julgado em 15/03/2006, DJ $02 / 10 / 2006$

${ }^{6}$ AgRg no RE 626.358/PE, Rel. Ministro. CEZAR PELUSO, TRIBUNAL PLENO, data de julgamento 22/03/2012, DJe $22 / 08 / 2012$.

${ }^{7}$ AgRg no AREsp 137.141/SE, Rel. Ministro ANTONIO CARLOS FERREIRA, QUARTA TURMA, julgado em 06/08/2013, DJe 15/08/2013. 
978.277/ $\mathrm{DF}^{8}$. No âmbito do STJ, em 2017, a Corte Especial também reviu seu posicionamento, no AgInt no AREsp 957.821/MS, sustentando a necessidade de comprovação quando da interposição, sob pena de intempestividade, tanto em atenção ao $\mathrm{CPC}$ como em respeito à nova orientação do $\mathrm{STF}^{9}$.

$\mathrm{O}$ assunto ganhou contornos ainda mais significativos no julgamento do AgInt no AREsp 1.311.512/SP pela Corte Especial do STJ, a fim de se analisar a necessidade de comprovação do feriado da segunda-feira de carnaval ${ }^{10}$. Em sessão ocorrida em 15.05.2019, converteu-se aquele agravo em recurso especial, a fim de possibilitar um debate mais amplo da matéria. No entanto, como aquele agravo dizia respeito à intempestividade do agravo em recurso especial, ao passo em que no AREsp 1.309.954/SP o debate girava em torno da intempestividade do próprio recurso especial, optou-se por converter esse em Recurso Especial - ganhando o número 1.813.684/SP - e o afetando à Corte Especial ${ }^{11}$.

No caso concreto, o recurso especial havia sido interposto em 09.03.2017 - quintafeira -, contra acórdão que havia sido publicado no dia 14.02.2017 - terça-feira, ressaltando-se que os dias 27 e 28 de fevereiro eram segunda e terça-feira de carnaval. Em seu voto, o relator, Ministro Raul Araújo, desenvolveu minucioso estudo acerca da extensão da palavra feriado, bem como do histórico do que se poderia considerar feriado nacional. Restou claro, nos termos do art. $5^{\circ}$ da Lei n. ${ }^{\circ} 1.408 / 51$, que a terça-feira de carnaval é dia em que não há expediente forense. $\mathrm{Na}$ Justiça Federal, de outra sorte, as Leis n. ${ }^{\circ}$ s 5.010/66 e 6.741/79 previram como "feriados" tanto a segunda como a terça-feira de carnaval. Para tanto, restaria claro que a segunda-feira de carnaval não é de ser considerado feriado forense perante os Tribunais de Justiça, salvo se houver lei local assim estabelecendo, o que demandaria a comprovação no ato da interposição do recurso. Concluiu o seu voto no sentido de que, a despeito de constituir feriado nacional apenas a terçafeira de carnaval, seria desnecessária a comprovação de tal feriado no ato de interposição do recurso, já que é fato público e notório que, há muitas décadas, não há expediente normal nas repartições públicas de sábado a terça-feira de carnaval. Para tanto, manifestou-se no sentido do conhecimento do recurso especial, reconhecendo-se a tempestividade.

Não foi esse voto que prevaleceu, no entanto. Acompanhou o relator o Ministro $\mathrm{Og}$ Fernandes. Os Ministros Francisco Falcão, Maria Thereza de Assis Moura e Nancy Andrighi

\footnotetext{
${ }^{8}$ ARE 978277 AgR, Rel. Ministro ROBERTO BARROSO, PRIMEIRA TURMA, julgado em 09/08/2016, DJe 3008-2016.

9 AgInt no AREsp 957.821/MS, Rel. Ministro RAUL ARAÚJO, Rel. p/ Acórdão Ministra NANCY ANDRIGHI, CORTE ESPECIAL, julgado em 20/11/2017, DJe 19/12/2017.

${ }^{10}$ AgInt no AREsp 1.311.512/SP, Rel. Ministro GURGEL DE FARIA, DJe 14/05/2019.

${ }^{11}$ REsp 1.813.684/SP, Rel. Ministro Raul Araújo, Rel. p/ Acórdão MinistroLuis Felipe Salomão, Corte Especial, julgado em 2/10/2019, DJe18/11/2019.
} 
votaram pelo não conhecimento do recurso. Por sua vez, os Ministros Herman Benjamim e Humberto Martins optaram, primeiramente, pela aplicação da regra do art. 932, parágrafo único (concessão de prazo de cinco dias para a comprovação) ${ }^{1213}$. Já o Ministro Luís Felipe Salomão abriu a divergência que restou vencedora, e foi acompanhado dos Ministros Herman Benjamim e Humberto Martins (que refluíram dos seus votos), Benedito Gonçalves, Laurita Vaz e Jorge Mussi.

A tese predominante foi no sentido de que, não obstante fosse o caso de reafirmar a jurisprudência daquela Corte, firmada no AREsp 957.281/MS, quanto à impossibilidade de comprovação posterior do feriado local, o STJ também deveria zelar pela segurança jurídica das relações sociais, pela proteção da confiança, pela isonomia e pela primazia da decisão de mérito, de sorte que a matéria em comento mereceria modulação de efeitos, até mesmo em respeito ao preconizado pelo art. 927, $\S 3^{\circ}$, do CPC. Para ele, portanto, como houve drástica mudança na jurisprudência das Cortes Superiores a respeito do tema, inclusive fruto de mudança legislativa, a exigência da comprovação do feriado local quando da interposição do recurso deveria se dar tão somente a partir da publicação do acórdão respectivo. Assim, conheceu-se do recurso especial, entendendo-o como tempestivo - mesmo tendo sido demonstrado o feriado posteriormente à interposição do recurso.

Suscitou-se Questão de Ordem, por parte da Ministra Nancy Andrighi, já após o trânsito em julgado do acórdão (publicação em 18.11.2019 e trânsito em julgado em 10.12.2019) e disponibilizadas as notas taquigráficas, diante de uma aparente contradição, a fim de que se pudesse identificar se a ideia contida era de abranger quaisquer feriados locais ou tão somente o feriado da segunda-feira de carnaval. Segundo a Ministra Nancy Andrighi, a proposta apresentada pelo Ministro Luís Felipe Salomão teria sido no sentido da modulação dos efeitos e da admissão da prova posterior apenas do feriado da segunda-feira de carnaval, no que teria sido objeto de acolhida de outros Ministros, formando maioria. No entanto, do voto do Ministro lançado aos autos, teria se identificado claramente a afirmação de que se aplicaria para todos e quaisquer feriados locais. Assim, propôs a questão de ordem para que se reconhecesse que a tese firmada era restrita ao feriado de segunda-feira de carnaval, não se aplicando aso demais feriados, inclusive aos feriados locais.

\footnotetext{
${ }^{12}$ Essa já era, inclusive, a posição defendida por Marco Antonio Rodrigues, no sentido de que, diante da ausência de expressa previsão de consequência pelo descumprimento de tal ônus, deveria ser aplicada a disposição geral do art. 932, parágrafo único, do CPC in Manual dos Recursos, Ação Rescisória e Reclamação. 1. Ed. São Paulo: Atlas, 2017 , p. $66 / 67$

${ }^{13}$ O Enunciado 66 da I Jornada de Direito Processual Civil do Conselho de Justiça Federal assim prevê: "Admite-se a correção da falta de comprovação do feriado local ou da suspensão do expediente forense, posteriormente à interposição do recurso, com fundamento no art. 932, parágrafo único, do CPC".
} 
O Ministro Luís Felipe Salomão divergiu, sustentando a impossibilidade de conhecimento da questão de ordem, porque oferecida após a coisa julgada, bem como, no mérito, argumentou que o amplo debate travado na Corte Especial não teria ficado restrito a apenas um ou outro feriado local, não havendo qualquer contradição a ser sanada.

Prevaleceu o posicionamento da Ministra Nancy Andrighi na linha de raciocínio de que aquele entendimento da Corte Especial, quanto à exigência de comprovação do feriado local somente após a publicação do acórdão, limitava-se à segunda-feira de carnaval. Dito acórdão ainda não transitou em julgado, porque foram oferecidos embargos de declaração pela Associação dos Advogados de São Paulo - AASP.

Ainda que não se tenha dado o trânsito em julgado da decisão oriunda da questão de ordem $^{14}$, desde então o STJ vem se deparando com o tema, atinente a outros feriados locais, e lamentavelmente tem aplicado aquela interpretação, de modo a não acatar o argumento de tempestividade, em razão da suspensão do prazo por conta de feriado local, mesmo que o recurso houvesse sido protocolado antes da publicação daquele acórdão de 2019, acarretando enorme prejuízo aos jurisdicionados e em evidente desrespeito à pretendida isonomia.

Tem-se notícia, inclusive, de que nos autos do AREsp $1.481 .810 / \mathrm{SP}^{15}$, o Ministro Luís Felipe Salomão, deparando-se com discussão quanto ao feriado local de fundação da cidade de São Paulo, resolveu propor aos colegas - no que foi acolhido na Quarta Turma - a afetação da questão à Corte Especial, para que se promova uma nova modulação do tema, de modo a estender os fundamentos que levaram à interpretação quanto à segunda-feira de carnaval a outros feriados locais notórios ${ }^{16}$.

Pois bem. Na linha do que defende Daniel Amorim Assumpção Neves (2016, p. 1.528), o dispositivo contido no $\S 6^{\circ}$ do art. 1.003 do CPC, além de contrariar sadia jurisprudência dos tribunais superiores, como expusemos linhas atrás, também está em dissonância com a tônica do $\mathrm{CPC} / 2015$, que visava a extirpar inúmeras hipóteses de jurisprudência defensiva.

De fato, não há como se negar uma clara discrepância da previsão do $\S 6^{\circ}$ do art. 1.003 do CPC em relação a tantos dos princípios consagrados como normas fundamentais pelo mesmo legislador de 2015, como a primazia do mérito, a boa-fé e a cooperação. Segundo bem ressalta Leonardo Carneiro da Cunha (2017, p. 108), o juiz deve, sempre que possível, superar os vícios, estimulando, viabilizando e permitindo a sua correção ou sanação, a fim de que possa efetivamente examinar o mérito e resolver o conflito posto pelas partes. Já para Artur Lins (2019,

\footnotetext{
${ }^{14}$ Até o fechamento deste texto, ainda não haviam sido julgados os embargos de declaração.

${ }^{15}$ AREsp 1.481.810/SP, Rel. Ministro JOÃO OTÁVIO DE NORONHA, julgado em 17/05/2019, DJe 21/05/2019.

${ }^{16} \mathrm{https}: / / \mathrm{m}$.migalhas.com.br/quentes/321414/stj-salomao-ira-propor-revisao-da-modulacao-relativa-ao-feriado-dasegunda-feira-de-carnaval. Acesso em: 31 mar.2020.
} 
p. 43), o princípio da primazia do julgamento de mérito persegue a solução do mérito da postulação como o estado ideal das coisas.

Parece-nos que o mais razoável seria aplicar a regra em compatibilidade com o disposto no parágrafo único do art. 932 do CPC, de modo a conceder ao recorrente - na hipótese de entender o julgador como indispensável a prova do feriado - o prazo de cinco dias para que se fizesse a demonstração, consoante os posicionamentos aqui já ressaltados de Marco Antonio Rodrigues e José Miguel Garcia Medina, e que foram - a priori - acolhidos nos votos dos Ministros Herman Benjamim e Humberto Martins, que acabaram refluindo posteriormente.

De todo modo, ainda que se tenha considerado ignorar - com o que, repita-se, não concordamos - o parágrafo único do art. 932 do CPC, o acórdão lavrado em outubro de 2019, da Corte Especial havia caminhado bem ao proceder à modulação da aplicação do $\S 6^{\circ}$ do art. 1.003 . Assim, como a jurisprudência do STF e do STJ passou anos consolidada quanto à desnecessidade de comprovação do feriado quando da interposição, coerente o posicionamento - levantado pelo Ministro Luís Felipe Salomão - de que a exigência de demonstração no ato de interposição do recurso deveria se dar tão somente após a publicação daquele acórdão, valorizando princípios como a segurança jurídica das relações sociais, a proteção da confiança, a isonomia e a primazia da decisão de mérito.

Por isso, causou estranheza a questão de ordem conhecida e tida por procedente, em fevereiro de 2020, ainda pendente de julgamento de embargos de declaração.

Primeiramente, pelo fato de que a coisa julgada já se havia operado sobre o acórdão publicado em novembro de 2019 e transitado em julgado no mês subsequente, razão pela qual, com a devida vênia, a questão de ordem sequer merecia conhecimento.

Ademais, em especial, no mérito, pelo fato de que a limitação da decisão ao feriado da segunda-feira de carnaval significou desperdiçar todos os ricos debates levados a efeito naquela Corte, deixando-se de lado a própria ratio do voto do Ministro Luís Felipe Salomão. Os valores e princípios que se buscaram preservar, a nosso ver, eram de ser aplicados a quaisquer feriados locais, não havendo qualquer sentido na restrição acolhida. A maioria formada na Corte Especial, quando do julgamento do mérito da questão de ordem, caminhou infelizmente na contramão do espírito que se buscou efetivar com o CPC/2015.

Resta-nos torcer que, ao se julgar os embargos de declaração oferecidos pela AASP, ou ao enfrentar a nova proposta de modulação suscitada no AREsp 1.481.810/SP, o STJ possa estender aqueles fundamentos determinantes, tão bem aprofundados em outubro passado, a todos e quaisquer feriados locais. 


\section{RECLAMAÇÃO É INADEQUADA PARA CONTROLE DA APLICAÇÃO DE TESE DE RECURSOS REPETITIVOS}

A Corte Especial do Superior Tribunal de Justiça extinguiu, por maioria, a Reclamação n. ${ }^{\circ}$ 36476/SP, por entender que esse meio processual não pode ser utilizado para controlar a aplicação, por Tribunais de $2^{\circ}$ grau, de precedentes do STJ firmados no julgamento de recursos especiais repetitivos ${ }^{17}$.

Como se sabe, a reclamação nasceu a partir da construção jurisprudencial, no Supremo Tribunal Federal. De acordo com Marco Antonio Rodrigues (2017, p. 359), nos anos de 1950 o STF já discutia longamente a respeito da possibilidade de criação de mecanismos para a efetivação de suas decisões, ainda que não houvesse expressa previsão constitucional ou legal, razão pela qual acabou se consolidando o uso da reclamação com base na aplicação da teoria dos poderes implícitos.

No Regimento Interno do STF, positivou-se a reclamação a partir de uma emenda introduzida em 1957, sendo mantida até a Constituição de 1967, que veio a atribuir força de lei às disposições do Regimento, que regulamentavam o processo e o julgamento dos feitos de sua competência, daí porque passou a reclamação a ter efetiva força normativa ordinária.

Na Constituição de 1988, a reclamação foi prevista nos arts. 102, I, alínea "i” e 105, I, alínea "f", para o STF e para o STJ, respectivamente, com o disciplinamento infraconstitucional por meio da Lei $n .^{\circ} 8.038 / 90$, que instituiu normas procedimentais para os processos que tramitassem junto ao STF e ao STJ. Como o CPC/2015 cuidou da reclamação entre os arts. 988 e 993, acabou por revogar alguns dispositivos da Lei n. ${ }^{\circ}$ 8.038/90 (art. 1.072, IV, CPC/2015).

Segundo Fredie Didier Jr. e Leonardo Carneiro da Cunha (2016, p. 533), em posição com a qual concordamos, a reclamação tem natureza jurídica de ação, de competência originária de tribunal, que visa à impugnação de ato judicial. Para tais autores, é ação, dentre outros fatores, porque depende de provocação de uma das partes ou do Ministério Público, bem como porque o acolhimento não ocorre no mesmo processo em que praticado o ato reclamado. Ademais, provoca não a anulação ou reforma da decisão, mas a sua cassação ou a avocação dos autos.

Sendo assim, nos termos da legislação processual civil em vigor, a reclamação tem cabimento para (i) preservar a competência do tribunal, (ii) garantir a autoridade das decisões do tribunal, (iii) garantir a observância de decisão do STF em controle concentrado de 
constitucionalidade e (iv) garantir a observância de enunciado de súmula vinculante, situações antes já consagradas pela Lei n. $^{\circ} 8.038 / 90$ e pela Lei n. ${ }^{\circ} 11.417 / 2016$.

Como inovações, o inciso IV do art. 988 previu a possibilidade de uso do instituto para garantir a observância de acórdão proferido em julgamento de incidente de resolução de demandas repetitivas ou de assunção de competência, bem como - e é aí onde reside a polêmica objeto desta análise -, no seu $\S 5^{\circ}$, em que possibilitou o uso da reclamação para garantir a observância de acórdão de recurso extraordinário com repercussão geral reconhecida ou de acórdão proferido em julgamento de recursos extraordinário ou especial repetitivos, mas apenas depois de esgotadas as instâncias ordinárias ${ }^{18}$.

A hipótese que desperta polêmica quanto ao cabimento da reclamação é, pois, a contida no $\S 5^{\circ}$ do art. 988 , acima mencionado. Ocorre que, na redação originária do CPC (Lei n. ${ }^{\circ}$ 13.105/2015), o inciso IV falava em uso da reclamação para garantir a observância de precedente proferido em julgamento de casos repetitivos. A redação foi alterada com a Lei n. ${ }^{\circ}$ 13.256/2016, que modificou o Código antes mesmo do início de sua vigência, em razão da pressão realizada pelos Tribunais Superiores, que não queriam a proliferação de reclamações, sob pena de inviabilizar o trabalho nessas Cortes.

Sendo assim, o inciso IV passou a prever que a reclamação caberia para garantir a observância de acórdão proferido em julgamento de IRDR ou de IAC, o que exclui, por interpretação literal, a possibilidade de uso contra precedentes firmados em recursos extraordinário ou especial repetitivos. Beatriz Galindo (2017, p. 47) critica a alteração promovida pela Lei n. ${ }^{\circ}$ 13.256/2016, sustentando que era mais adequado o modelo da redação original, pois previa os mesmos requisitos em qualquer das três hipóteses de cabimento relacionadas ao sistema de precedentes (recursos repetitivos, IAC e IRDR).

\footnotetext{
${ }^{18}$ Art. 988. Caberá reclamação da parte interessada ou do Ministério Público para:

I - preservar a competência do tribunal;

II - garantir a autoridade das decisões do tribunal;

III - garantir a observância de decisão do Supremo Tribunal Federal em controle concentrado de constitucionalidade;

III - garantir a observância de enunciado de súmula vinculante e de decisão do Supremo Tribunal Federal em controle concentrado de constitucionalidade;

IV - garantir a observância de enunciado de súmula vinculante e de precedente proferido em julgamento de casos repetitivos ou em incidente de assunção de competência.

IV - garantir a observância de acórdão proferido em julgamento de incidente de resolução de demandas repetitivas ou de incidente de assunção de competência;

(...)

$\S 5^{\circ}$ É inadmissível a reclamação:

I - proposta após o trânsito em julgado da decisão reclamada

II - proposta para garantir a observância de acórdão de recurso extraordinário com repercussão geral reconhecida ou de acórdão proferido em julgamento de recursos extraordinário ou especial repetitivos, quando não esgotadas as instâncias ordinárias.
} 
No entanto, alterou-se também o $\S 5^{\circ}$ do artigo 988 , de modo a indicar, em seu inciso II, que a reclamação seria inadmissível se proposta para garantir a observância de acórdão de recurso extraordinário com repercussão geral reconhecida ou de acórdão proferido em julgamento de recursos extraordinário ou especial repetitivos, quando não esgotadas as instâncias ordinárias. Esse trecho é fundamental e consta da norma, é importante ressaltar. Para José Carlos Baptista Puoli (2016, p. 506), essa limitação ou condicionamento do uso da reclamação é fator veemente a confirmar não estar suficientemente madura a aplicabilidade de um sistema de precedentes vinculantes em nossa cultura jurídica.

Assim, sob a nossa ótica, a contrario sensu, o parágrafo em referência viabiliza a reclamação para garantir a observância de precedentes fruto de recurso extraordinário com repercussão geral reconhecida ou de recursos repetitivos, mas desde que tenham sido esgotadas as vias ordinárias. Outra não pode ser a interpretação, sob pena de se esvaziar o sentido literal da norma. Sim, dizemos literal porque está expresso "quando não esgotadas as instâncias ordinárias". Ressalte-se que, de outra sorte, como ensina Leonardo Carneiro da Cunha (2016, p. 694), se o órgão julgador não segue o precedente na decisão, não cabe a reclamação, mas sim embargos de declaração, já que não cabe reclamação por omissão.

É do próprio STJ que se extrai a definição de "instâncias ordinárias", constantemente inserida nos seus acórdãos para designar os julgamentos proferidos pelos juízes de primeiro grau, Tribunais de Justiça e Tribunais Regionais Federais.

A título de ilustração, dentro vários, confiram-se os AgInt no AREsp 887.868/ $\mathrm{PE}^{19}$, AgRg no AREsp 390.919/SC ${ }^{20}$, e AgInt na PET no REsp 1577870/DF ${ }^{21}$, no qual se verifica o seguinte trecho de sua ementa:

$\mathrm{O}$ inciso III do $\S 4^{\circ}$ do art. 942 do $\mathrm{CPC} / 2015$, quando faz referência à palavra "tribunais", deve ser interpretado como as instâncias ordinárias competentes para o julgamento da Apelação, ou seja, os Tribunais de Justiça e o Tribunais Regionais Federais, e não as instâncias extraordinárias.

Evidente, portanto, que a ideia de "instâncias ordinárias", inserida no CPC, diz respeito aos Tribunais de Justiça e TRFs, como exaustivamente tratado pelo STJ.

Todavia, mesmo com essa definição pré-estabelecida, a Corte entendeu não ser cabível a reclamação.

\footnotetext{
${ }^{19}$ AgInt no AREsp 887.868/PE, Rel. Ministro NAPOLEÃO NUNES MAIA FILHO, PRIMEIRA TURMA, julgado em 08/04/2019, DJe 11/04/2019.

${ }^{20}$ AgRg no AREsp 390.919/SC, Rel. Ministro RAUL ARAÚJO, QUARTA TURMA, julgado em 22/04/2014, DJe $19 / 05 / 2014$

${ }^{21}$ AgInt na PET no REsp 1577870/DF, Rel. Ministro HERMAN BENJAMIN, SEGUNDA TURMA, julgado em 15/12/2016, DJe 06/03/2017.
} 
Cássio Scarpinella Bueno (2016, p. 655) já antevia a possibilidade de entendimento como o firmado no STJ, mas sustenta que, para ele, é plenamente cabível a reclamação após esgotadas as instâncias ordinárias, de modo que, do agravo interno contra a decisão que negou seguimento ao Recurso Especial, por aplicação equivocada de recurso repetitivo, é irrecusável o cabimento de novo recurso extraordinário ou especial e, se for o caso, o emprego da própria reclamação, encontrando eco seguro no já falado inciso II do $§ 5^{\circ}$ do art. 988 .

Foi exatamente essa situação que chegou à Corte Especial do STJ, qual fosse, uma reclamação que objetivava à cassação de uma decisão por inadequada aplicação de precedente oriundo de recurso especial repetitivo.

No caso em análise, estava-se diante de pedido de cumprimento individual de sentença, formulada contra empresa de telefonia, a qual havia sido condenada, nos autos de ação civil pública ajuizada pelo Ministério Público do Estado de São Paulo, à emissão da diferença de ações, ou a pagar os respectivos valores, aos consumidores que, mediante contrato de participação financeira, adquiram plano de expansão de linha telefônica, na forma mais favorável ao consumidor. O tema da ação é importante para se perceber o ponto de destaque no objeto da reclamação.

Em decisão interlocutória, houve a inversão do ônus da prova, de modo a que a empresa providenciasse a documentação necessária à demonstração de que teria entregue o valor correto de ações aos consumidores, com a determinação de que o pagamento do equivalente em pecúnia deveria ser calculado de acordo com a cotação do fechamento do pregão da Bolsa de Valores da data da entrega das ações a menor. Tal decisão levou a empresa a interpor agravo de instrumento junto ao Tribunal de Justiça do Estado de São Paulo, que não foi provido.

Ocorre que, ao julgar embargos de declaração contra tal acórdão, o TJSP deu-lhes provimento, a fim de esclarecer que, não sendo possível a entrega das ações, o valor da indenização deveria corresponder ao número de ações a que a parte tinha direito na data da integralização, multiplicado por sua cotação na Bolsa de Valores no dia do trânsito em julgado da demanda.

Isso levou os exequentes à interposição de recurso especial, com base na alínea "a" do art. 105, III, da Constituição Federal, argumentando, dentre outros aspectos, que era inaplicável o critério de conversão fixado pelo STJ no Recurso Especial repetitivo n. ${ }^{\circ}$ 1.301.989/RS ${ }^{22}$. E foi com base em tal precedente que o TJSP negou seguimento ao recurso especial, sustentando que se aplicaria ao caso a aludida tese (tema 658): "Converte-se a

${ }^{22}$ REsp 1301989/RS, Rel. Ministro PAULO DE TARSO SANSEVERINO, SEGUNDA SEÇÃO, julgado em 12/03/2014, DJe 19/03/2014. 
obrigação de subscrever ações em perdas e danos multiplicando-se o número de ações devidas pela cotação destas no fechamento do pregão da Bolsa de Valores no dia do trânsito em julgado da ação de complementação de ações, com juros de mora desde a citação". Contra a decisão monocrática de negativa de seguimento, foi interposto agravo interno, que não foi provido sob fundamentos idênticos.

Diante disso, entenderam por bem os exequentes por oferecer Reclamação ao STJ, quando aduziram ser o precedente inaplicável ao caso concreto, já que a pretensão deles era a de obter indenização do valor das ações entregues a menor, e não de emissão de tais ações, com eventual conversão em perdas e danos. Ademais, defenderam que a data em que se deu a formação da coisa julgada somente deveria ser o marco financeiro para quem desejava receber as ações e não para quem pede a reparação financeira pelo prejuízo sofrido com a entrega a menor. Fizeram, portanto, um distinguishing.

A matéria foi distribuída inicialmente à Segunda Seção do STJ, mas aquele colegiado entendeu por bem afetar à Corte Especial, em função da relevância da controvérsia e com o fito de prevenir divergência entre as seções.

Em seu voto, a Ministra relatora desenvolveu um minucioso estudo acerca da reclamação, partindo de sua gênese, passando pela sua aplicação anterior ao CPC/2015, até chegar à análise do instituto sob a égide da legislação em vigor, em especial após a reforma operada pela Lei n. ${ }^{\circ} 13.256 / 2016$.

De acordo com a Ministra, na redação original, o inciso IV do art. 988 do CPC/2015 previa o cabimento do instituto para garantir a observância de enunciado de súmula vinculante e de precedente proferido em julgamento de casos repetitivos ou em incidente de assunção de competência.

No entanto, a Lei n. ${ }^{\circ} 13.256 / 2016$, que alterou o CPC antes mesmo dele entrar em vigor, alterou a redação do inciso IV, de modo a excluir os casos repetitivos das hipóteses de cabimento. De outra sorte, segundo a relatora, o $\S 5^{\circ}$ do mesmo artigo teria estabelecido a inadmissão da reclamação proposta para garantir a observância de acórdão de recurso especial repetitivo, mas apenas quando não esgotadas as instâncias ordinárias. A Ministra fez menção ainda à Exposição de Motivos do Projeto de Lei n. ${ }^{\circ} 2.468 / 2015$, que resultou na lei que alterou o CPC, em que teria restado clara a intenção de não sobrecarregar os tribunais superiores, dispensando-os do julgamento de reclamações e agravos que tivessem por objeto temas decididos em recursos repetitivos e em repercussão geral.

$\mathrm{Na}$ linha de raciocínio da relatora, se um precedente fruto de um recurso repetitivo foi aplicado erroneamente, a revisão está assegurada pela via recursal ordinária, até culminar no 
julgamento do agravo interno no tribunal local, de modo que se a reclamação fosse recebida, estar-se-ia atentando contra a própria finalidade da instituição de um regime próprio dos repetitivos.

Por outro lado, houve divergência de entendimento, e ainda que não tenha sido a tese vencedora, a nosso ver, é a interpretação correta a ser dada ao cabimento de reclamação nesses casos.

Afirmou o voto divergente que a reclamação é instrumento fundamental para garantir a eficácia dos precedentes indicados pelo Código de Processo Civil como obrigatórios. Desse modo, a reclamação, como no caso concreto, seria importante para se verificar o acerto, ou não, do Tribunal a quo na aplicação da tese firmada em repetitivos, desde que esgotadas as instâncias ordinárias.

Isso porque, conforme pensamos, seria a forma de fixar a devida aplicação dos precedentes pelos Tribunais de segundo grau, mantendo a jurisprudência estável e harmônica, e incentivando, assim, a cultura de respeito, pelas instâncias ordinárias, aos precedentes firmados em recurso especial e extraordinários repetitivos.

Nem se diga, como fez a relatora, que a Lei n. ${ }^{\circ} 13.256 / 2016$, que alterou o CPC antes mesmo de este entrar em vigor, alterou a redação do inciso IV, de modo a excluir os casos repetitivos das hipóteses de cabimento. A redação do art. $988, \S 5^{\circ}$, do CPC diz exatamente o contrário, de modo que essa afirmação, em verdade, destoa da literalidade da norma.

O voto divergenteconsignou que o referido dispositivo legal, como já afirmamos anteriormente, apenas exigiu o prévio esgotamento das instâncias ordinárias, tal como consta na literalidade do dispositivo, evitando que toda decisão judicial, em qualquer grau de jurisdição, pudesse ser questionada direta e imediatamente por meio de reclamação.

No âmbito do Supremo Tribunal Federal, felizmente não parece ser esse o entendimento, visto que várias reclamações - contra a desobediência aos precedentes formados em recurso extraordinário com repercussão geral - têm chegado àquela Corte Superior, as quais, via de regra, são admitidas, desde que esgotadas as vias recursais ordinárias. Do contrário, quando há a extinção da reclamação sem resolução do mérito, o fundamento não é o utilizado pelo STJ, mas exatamente a indicação de que, nos termos do inciso II do $\S 5^{\circ}$ do art. 988, exige-se o esgotamento da via recursal ordinária ${ }^{23}$.

23 Neste sentido, Rcl 29664/SP, Rel. Ministro ROBERTO BARROSO, PRIMEIRA TURMA, julgamento 27/04/2018, publicação 13/06/2018, Rcl 29987/ES, RelMinistro DIAS TOFFOLI, SEGUNDA TURMA, julgamento 07/05/2018, publicação 28/05/2018, Rcl 30344/SP, Rel. ROBERTO BARROSO, PRIMEIRA TURMA, julgamento 04/06/2018, publicação 15/06/2018, Rcl 33419/ES, Rel. Ministro ROBERTO BARROSO, PRIEMIRA TURMA, julgamento 29/03/2019, publicação 30/04/2019, Rcl 26674/SP, Rel. Ministro ROBERTO BARROSO, PRIMEIRA 
Em conclusão, ousamos discordar da maioria formada na Corte Especial do STJ. Da forma que restou decidido, o $§ 5^{\circ}$, inciso II, do art. 988 do CPC tornar-se-á "letra morta" no CPC, perdendo a razão de ser. Mantido esse entendimento, temos que o referido parágrafo deverá ser "não lido" pelos aplicadores do direito, porque não há outra razão para deixar de aplicar algo que está literalmente ali escrito.

A nosso ver, é coerente a exigência de esgotamento das instâncias ordinárias, a fim de que a reclamação não seja utilizada como verdadeiro sucedâneo recursal, ou mesmo para que se encurte a chegada da questão às Cortes Superiores, antes mesmo de serem decididas em segunda instância.

Não raras vezes, o tribunal local deixa de aplicar ou aplica indevidamente o precedente qualificado que se produziu no recurso extraordinário com repercussão geral ou no recurso excepcional repetitivo.

Fazer com que a discussão quanto essa indevida aplicação se finde no julgamento do agravo interno pelo próprio tribunal local, sem que o tema chegue ao tribunal superior em que se gerou o precedente, ainda que se vise à celeridade e que se pretenda evitar a sobrecarga no STJ, acaba por atentar contra as pretendidas coerência, segurança e estabilidade do microssistema de precedentes qualificados, além de expressamente apagar o que está escrito em dispositivo legal.

\section{4 É POSSÍVEL A INTERPOSIÇÃO DE RECURSO ESPECIAL CONTRA DECISÕES MONOCRÁTICAS?}

De modo atípico, a Primeira Turma do Superior Tribunal de Justiça admitiu Recurso Especial interposto para atacar decisão monocrática de tribunal inferior, no âmbito do Agravo Interno no Agravo em Recurso Especial n. ${ }^{0} 1.156 .112 / \mathrm{SP}^{24}$.

Como se sabe, os recursos excepcionais - extraordinário e especial - guardam previsão constitucional, respectivamente nos arts. 102, III e 105, III da Carta Maior, não sendo admissíveis como integrantes da ordinária rotina recursal, mas sim apenas e tão somente quando enquadrados naquelas taxativas hipóteses descritas nas alíneas dos respectivos dispositivos constitucionais.

Ademais, enquanto excepcionais, obedecem a pressupostos que vão além daqueles já tradicionalmente verificados para os demais recursos (tempestividade, motivação, forma,

TURMA, julgamento 30/08/2019, publicação 17/09/2019, Rcl 32101/SP, Rel. Ministro LUIZ FUX, PRIMEIRA TURMA, julgamento 25/10/2019, publicação 22/11/2019.

24 AgInt no AREsp 1156112/SP, Rel. Ministro GURGEL DE FARIA, PRIMEIRA TURMA, julgado em $16 / 08 / 2018$, DJe 11/10/2018. 
adequação, recorribilidade, preparo, dentre outros), consubstanciados em pressupostos específicos, alguns decorrentes da interpretação do texto constitucional, outros objetos de súmulas editadas pelo Supremo Tribunal Federal ou pelo Superior Tribunal de Justiça. Deve o recorrente, pois, para interpor um recurso extraordinário ou especial, demonstrar o prequestionamento da matéria, além de não ter a possibilidade de usar os recursos para discutir matérias que importem em reexame do arcabouço probatório (Súmula 279/STF e 7/STJ).

Mas há outra especificidade, presente na interposição dos recursos extraordinário e especial, que por vezes intriga os recorrentes, e é ora o nosso objeto deste estudo: a necessidade do prévio esgotamento das vias recursais ordinárias.

Desde as primeiras lições de qualquer estudante nos bancos de uma faculdade de direito, aprende-se que, mesmo se estiver clara a violação a um dispositivo de lei ou constitucional, não se pode "pular" instâncias, interpondo diretamente os recursos extraordinariamente previstos na Constituição, de modo que o recorrente precisará se valer de todas as vias possíveis, ainda na via ordinária, para tentar modificar a decisão, antes que venha a usar os recursos contidos nos arts. 102, III e 105, III, da Constituição.

Trata-se, portanto, da vedação de interposição dos recursos excepcionais per saltum, como afirmam Fredie Didier Jr. e Leonardo Carneiro da Cunha (2016, p. 313), no sentido de que não se pode ignorar uma previsão de recurso ordinário contra a decisão. $\mathrm{Na}$ lição de Vinicius Silva Lemos (2016, p. 325), se ainda há, no próprio tribunal em que o processo tramita, possibilidade recursal, não há motivos de buscar a solução via recurso excepcional, se o tribunal ainda pode solucionar a questão, dentro de um trâmite recursal mais simples, com admissibilidade mais simplória e, certamente, mais célere.

Para Marco Antonio Rodrigues (2017, p. 252), o uso dos recursos excepcionais deve ser a última hipótese do jurisdicionado, sendo tal característica extraída do art. 102, III, da CRFB e do art. 105, III, da CRFB, uma vez que ambos os dispositivos, ao cuidarem do cabimento de tais recursos, preveem sua interposição em face de decisão proferida em única ou última instância. Para ele, ainda, inaplicável a fungibilidade entre o recurso excepcional e o agravo interno, em razão de se estar diante de erro grosseiro do recorrente.

A título de exemplo, pouco importa se numa decisão interlocutória concessiva de tutela provisória de urgência antecipada, houver violação explícita a um dispositivo de lei federal, pois não há como se interpor diretamente o recurso especial. Precisará o recorrente se valer do agravo de instrumento para somente então, derrotado no agravo, interpor recurso especial contra o acórdão. Isso se o agravo de instrumento não houver sido julgado monocraticamente, com fulcro no art. 932, incisos III, IV ou V, do CPC, quando o recorrente 
precisará, antes ainda de se valer do recurso especial, interpor o agravo interno do art. 1.021 do CPC.

De outra sorte, e utilizando a mesma linha de raciocínio, ainda que uma sentença de primeiro grau ofenda cabalmente um dispositivo constitucional, o perdedor precisará apelar ao tribunal de segundo grau para, mais uma vez derrotado, e sendo a decisão colegiada, usar o recurso extraordinário. Houvesse sido monocrático o julgado da apelação, precisaria previamente interpor o agravo interno para forçar uma decisão colegiada e, aí sim, recorrer extraordinariamente.

A interpretação que se extrai do art. 102, III, e do art. 105, III, ambos do texto constitucional, é de que o exaurimento da instância recursal é, de fato, um requisito para a interposição dos recursos na via excepcional.

O STF, inclusive, chegou a sumular o tema, no Enunciado 281, ao estatuir que "é inadmissível o recurso extraordinário, quando couber, na justiça de origem, recurso ordinário na decisão impugnada". No STJ, apesar de não haver enunciado específico, como fez o STF, a ratio da Súmula 281 do STF foi observada quando da edição da Súmula 207, que afirma ser inadmissível o recurso especial quando cabíveis embargos infringentes contra acórdão no tribunal de origem.

Ocorre que, ainda que incomum, possível é que um recorrente se depare com situações nas quais, não obstante tenha buscado exaurir a instância ordinária, perseguindo uma decisão colegiada, aquela acaba por não se esgotar, em decorrência de uma sequência de decisões monocráticas.

Sentindo-se prejudicado, coloca-se diante do seguinte questionamento: o que fazer para forçar o necessário esgotamento da via recursal ordinária e, por conseguinte, possibilitar o conhecimento do eventual recurso excepcional?

Uma das opções, a nosso ver, é a impetração de um mandado de segurança, a fim de atacar ato judicial - objeto de decisão de Desembargador de Tribunal de Justiça ou de Tribunal Regional Federal - que está a negar a aplicação do princípio da colegialidade e, ao mesmo tempo, a impedir o exercício da plena recorribilidade. Ocorre, por outro lado, que o remédio haverá de ser impetrado junto ao próprio tribunal, a teor do art. 108, I, “c”, aplicável simetricamente aos Tribunais de Justiça dos Estados e do Distrito Federal.

Desse modo, por exemplo, se o regimento interno do respectivo tribunal eventualmente prever que o relator seja o mesmo que está sistematicamente prolatando decisões monocráticas para obstar o esgotamento da via ordinária, possível é que também o faça no julgamento do remédio constitucional, o que não resolveria a situação intrigante. 
Tal questão chegou ao STJ em 2002, quando do julgamento do Mandado de Segurança n. ${ }^{\circ} 8.093 / \mathrm{DF}^{25}$. A questão, no caso concreto, dizia respeito a ato judicial, praticado por outro Ministro, relator do EREsp n. ${ }^{\circ}$ 244.489/SP, visto que o agravo regimental interposto contra decisão monocrática em embargos de divergência também foi fruto de decisão monocrática, suprimindo o julgamento pela Seção. Observa-se que, nesse caso concreto, o tema só foi objeto de análise pelo STJ porque a decisão monocrática atacada era de Ministro daquela Corte Superior.

$\mathrm{Na}$ ocasião, concedeu-se a segurança, ao se entender que, não se conformando a parte com a decisão do relator, recorrendo ao colegiado pela via do agravo regimental, era defeso ao relator suprimir o recurso da apreciação colegiada, por mais absurdo que fosse.

O problema é que, na eventualidade de uma decisão monocrática advir de Desembargador de TRF ou de TJ, o mandado de segurança não terá praticamente nenhuma eficácia, já que, sendo do próprio tribunal a competência do julgamento, possível é que sejam mantidas, de modo monocrático, as decisões anteriores, não chegando ao STJ a questão.

Não obstante, em 2018 o tema foi levado ao STJ, desta feita pela via recursal e não por meio do remédio constitucional referido no parágrafo anterior, cenário ainda mais complexo. Cuidava-se, na origem, de agravo de instrumento interposto no Tribunal Regional Federal da $3^{\mathrm{a}}$ Região, a fim de atacar decisão que julgara procedente impugnação ao valor da causa, atribuindo a uma ação anulatória de débito fiscal o valor de R\$ 397.953.778,49 (trezentos e noventa e sete milhões, novecentos e cinquenta e três mil, setecentos e setenta e oito reais e quarenta e nove centavos). Naquela Corte Regional, o Relator sorteado entendeu por bem negar seguimento ao agravo, em decisão monocrática, fundamentando-o com base no art. 557, caput, do CPC/73, considerando o recurso como manifestamente improcedente.

Daquele decisum, houve-se por interpor agravo interno, que por sua vez não foi conhecido, por se compreender que o agravo interno era manifestamente inadmissível, aplicando-se, já sob a égide do art. 1.021 do CPC/2015, multa de 1\% (um por cento) sobre o valor da causa. $\mathrm{O}$ argumento do relator, à ocasião, foi o de que o recorrente não se desincumbiu do ônus de impugnar especificamente os fundamentos da decisão recorrida. Tal decisão, registrese, foi colegiada.

Começava, a partir daí, a via crucis do recorrente.

Detectando supostas omissões e contradições no acórdão da turma do TRF/3a Região, opôs embargos declaratórios, inclusive por não ter sido analisado o descabimento da multa em

${ }^{25}$ MS 8.093/DF, Rel. Ministra ELIANA CALMON, CORTE ESPECIAL, julgado em 15/05/2002, DJ 21/10/2002, p 263. O julgamento se deu em 15.05.2002, sendo decidido por maioria na Corte Especial do STJ. 
obediência ao precedente contido no REsp n. ${ }^{\circ} 1.198 .108 / \mathrm{RS}^{26}$. Contudo, o desembargador relator não conheceu, monocraticamente, dos embargos de declaração, sustentando para tanto que o art. $1.021, \S 5^{\circ}$, do $\mathrm{CPC} / 2015$, impõe o recolhimento da multa de $1 \%$ arbitrada no julgamento do agravo interno. Sendo assim, a empresa interpôs novo agravo interno, que desta vez não foi conhecido, igualmente por decisão monocrática, sob o mesmo fundamento do não recolhimento da multa.

Diante disso, foi interposto recurso especial, sustentando que se estaria a violar o próprio art. 1.021 do $\mathrm{CPC}$ (caput e $\S 4^{\circ}$ ), já que o agravo interno contra a decisão que negou provimento ao agravo de instrumento era cabível, ao impugnar especificamente os fundamentos decisórios, bem como porque não poderia ser manifestamente inadmissível se interposto mesmo visando apenas ao exaurimento da instância ordinária para acesso à via excepcional.

Argumentou ainda a contrariedade ao art. 1.030, II, do CPC/2015, pois o STJ já teria firmado entendimento em sede de julgamento submetido ao rito dos recursos repetitivos acerca

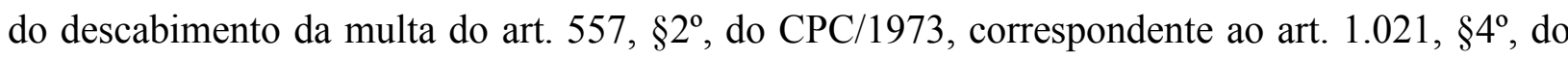
atual estatuto processual, razão pela qual a Presidência do Tribunal a quo deveria ter encaminhado os autos ao órgão julgador para a realização do juízo de retratação, com a imediata cassação da multa de $1 \%$ do valor da causa (quantia milionária) equivocadamente imposta à recorrente, e a determinação do julgamento dos embargos de declaração, de forma colegiada, regularmente opostos conta o acórdão que julgou o agravo interno. Finalmente, aduziu a divergência jurisprudencial com o julgado no REsp n. 1.198.108, no sentido da não aplicação da multa prevista no agravo interno interposto com o fim de esgotamento da instância ordinária para o fim de interposição do recurso especial ${ }^{27}$.

No juízo de admissibilidade dos recursos excepcionais, nem o especial e nem o extraordinário foram admitidos, sob o fundamento do não esgotamento da via recursal ordinária, forçando a interposição do agravo do art. 1.042 do CPC. Chegando à Presidência do STJ, não foi conhecido porque o recurso especial teria sido interposto contra decisão monocrática do tribunal de origem. Finalmente se chegou ao agravo interno contra a decisão do Presidente do STJ,objeto aqui de análise.

\footnotetext{
${ }^{26}$ Em tal julgado, sob a relatoria do Ministro Mauro Campbell Marques, na Corte Especial (julgamento em 17.10.2012), decidiu-se que não há falar em recurso de agravo manifestamente infundado ou inadmissível, em razão da interposição visar o esgotamento da instância para acesso aos Tribunais Superiores, uma vez que a demanda somente foi julgada por meio de precedentes do próprio Tribunal de origem. Assim, é manifesto que a multa imposta com fundamento no art. 557, $\$ 2^{\circ}$, do CPC deve ser afastada.

${ }^{27}$ REsp 1833718/SP, Rel. Ministro HERMAN BENJAMIN, SEGUNDA TURMA, julgado em 03/10/2019, DJe $11 / 10 / 2019$.
} 
No voto, acolhido à unanimidade, entendeu-se como exaurida a instância ordinária, visto que o recorrente teria se utilizado de todos os meios processuais disponíveis para assegurar tal exaurimento, a fim de interpor os recursos às instâncias superiores.

Assim, acabou-se por dar provimento ao agravo interno, para conhecer do agravo do art. 1.042 do CPC, e dar provimento ao recurso especial, com o fim de afastar a multa aplicada na instância inferior, determinando o seu retorno àquele TRF/3, para a realização do julgamento dos embargos de declaração pelo órgão colegiado.

A nosso ver, agiu acertadamente a Primeira Turma do STJ. No caso concreto, não se pode argumentar que a parte recorrente não teria se desincumbido do ônus do esgotamento da via recursal ordinária. O ponto inicial do equívoco parece ter se dado quando, ao se opor embargos declaratórios contra o acórdão do interno, foram eles julgados monocraticamente.

Posteriormente, o erro persistiu, quando o agravo interno interposto contra a decisão monocrática que não conhecera dos embargos de declaração pelo não recolhimento da multa de $1 \%$, não foi submetido a uma decisão colegiada. A partir daí, houve uma sucessão de equívocos, quer na admissibilidade do recurso especial no tribunal de origem, quer na admissibilidade na Presidência do STJ, que não tiveram, pelo TRF, a coerente compreensão observada no âmbito da Primeira Turma.

Não se está aqui a defender, como igualmente não pretendeu aquele recorrente no caso concreto, a interposição per saltum dos recursos excepcionais. Se há possibilidade de modificação da decisão na via ordinária, esta pode e deve ser observada. No entanto, a reiterada inadmissão ou não conhecimento monocrático de recursos, que deveriam ser julgados de modo colegiado, fazendo impedir a possibilidade de a essa colegialidade dos tribunais inferiores apreciar e esgotar tal via, não pode servir de condão ou de justificativa para filtrar indevidamente os recursos excepcionais a serem eventualmente interpostos.

Não faz sentido - e isso é algo que merece a reflexão não apenas dos nossos tribunais, mas também dos legisladores - que uma discussão como essa, fruto de uma filigrana processual, acabe por prejudicar tanto a parte, seja ela privada ou pública. Para se ter uma ideia, o agravo de instrumento naqueles autos foi interposto em 17.03.2016, ao passo em que os embargos declaratórios, cujo julgamento será retomado quando os autos retornarem ao TRF/3, são datados de 12.09.2016.

São, portanto, mais de três anos perdidos de tramitação processual, tudo fruto das sucessivas tentativas de se filtrar indevidamente e impedir a legítima utilização da via recursal. Não é crível, não é razoável, não é lógico. Que situações como essa não tornem a ocorrer. 


\section{CONCLUSÃO}

Desses três casos acima analisados, pode-se extrair a dificuldade que se verifica atualmente na aplicação do Código de Processo Civil de 2015, em razão da sua pouca idade e dos inúmeros questionamentos que ele suscita, haja vista exatamente o pouco tempo que a doutrina e a jurisprudência tiveram de vê-lo ser aplicado na prática.

Tratou-se aqui de contagem de prazo, reclamação, e cabimento de recurso especial, três temas regulados pelo Código, mas que o legislador deixou margem de dúvida, dirimida pelo Superior Tribunal de Justiça, órgão do Poder Judiciário responsável por uniformizar a interpretação da legislação federal.

Vários outros temas chegaram e ainda chegarão ao STJ, para que ele decida qual a aplicação correta da norma processual. Outros tantos talvez por lá não aportem, haja vista os limites constitucionais para a apreciação de um recurso por nossa Corte Superior. Nesses casos, caberá aos Tribunais de segunda instância e à doutrina a pacificação de eventuais dúvidas que surjam da leitura das regras processuais.

\section{REFERÊNCIAS}

BUENO, Cássio Scarpinella. Manual de direito processual civil. 2. ed. São Paulo: Saraiva, 2016.

CUNHA, Leonardo Carneiro da.Fazenda Pública em juízo. 13. ed. Rio de Janeiro: Forense, 2016.

CUNHA, Leonardo Carneiro da. Normas fundamentais no novo CPC Brasileiro. In:SILVA, João Calvão da; CUNHA, Leonardo Carneiro da; CAPELO, Maria José; THOMAZ, Osvir Guimarães. Processo Civil Comparado: análise entre Brasil e Portugal. Rio de Janeiro: Forense, 2017.

DIDIER JR., Fredie; CUNHA, Leonardo Carneiro da.Curso de Direito Processual Civil: o processo civil nos tribunais, recursos, ações de competência originária de tribunal e querela nullitatis, incidentes de competência originária de tribunal. 13. ed. Salvador: Jus Podivm, 2016.

GALINDO, Beatriz Magalhães. O precedente decorrente do julgamento de recursos repetitivos pode ser considerado de obrigatoriedade em sentido forte? In: GALINDO, Beatriz Magalhães; KOLBACH, Marcela. Recursos no CPC/2015: perspectivas, críticas e desafios. Salvador: Editora JusPodivm, 2017.

JORGE, Flávio Cheim. Comentários ao art. 1.003 do CPC. In:WAMBIER, Teresa Arruda Alvim; DIDIER JR., Fredie; TALAMINI, Eduardo; DANTAS, Bruno. Breves Comentários ao Novo Código de Processo Civil. 3. ed. São Paulo: Editora Revista dos Tribunais, 2016.

LEMOS, Vinicius Silva. Recursos e Processos nos Tribunais. 2. ed. São Paulo: Lexia, 2016. 
LINS, Artur Orlando. A primazia do julgamento de mérito no processo civil brasileiro. Salvador: Editora JusPodivm, 2019.

MEDINA, José Miguel Garcia. Novo Código de Processo Civil Comentado. 4. ed. São Paulo: Editora Revista dos Tribunais, 2016.

NEVES, Daniel Amorim Assumpção. Manual de Direito Processual Civil: volume único. 8. ed. Salvador: Ed. Jus Podivm, 2016.

PUOLI, José Carlos Baptista. Precedentes Vinculantes? O CPC “depois” da Lei n. ${ }^{\circ}$ 13.256/16. In:LUCON, Paulo Henrique dos Santos; APRIGLIANO, Ricardo de Carvalho; SILVA, João Paulo Hecker; VASCONCELOS, Ronaldo; ORTHMANN, André. Processo em Jornadas. Salvador: Editora Jus Podivm, 2016.

RODRIGUES, Marco Antonio. Manual dos Recursos, Ação Rescisória e Reclamação. São Paulo: Atlas, 2017. 